
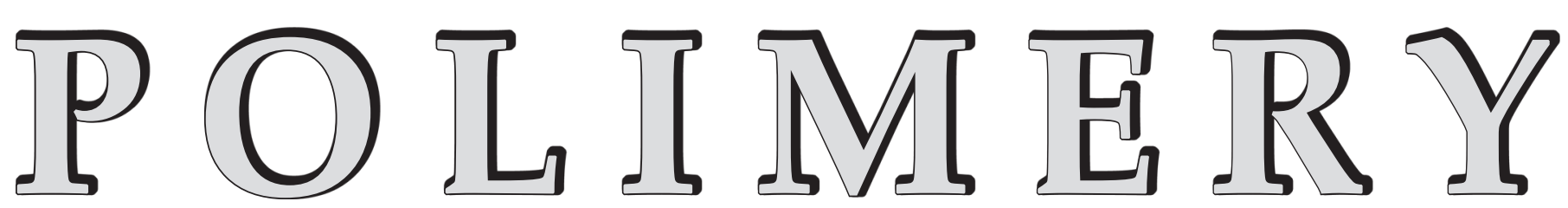

\title{
Nanogels obtained by gamma radiation induced polymerization*)
}

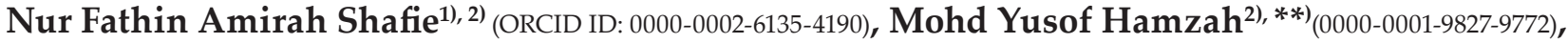 \\ Roshafima Rasit Alii) ${ }^{10000-0002-9227-4441)}$
}

DOI: dx.doi.org/10.14314/polimery.2021.9.1

\begin{abstract}
The influence of 2-(dimethylamino)ethyl methacrylate (DMAEMA) concentration on the temperature sensitivity of nanogels based on $\mathrm{N}$-isopropylacrylamide (NIPAAM), poly(vinylpyrrolidone) (PVP), poly(ethylene glycol) diacrylate (PEGDA) by gamma radiation induced polymerization was investigated. Dynamic light scattering (DLS) and zeta potential measurements were used to characterize the nanogels. Temperature has been found to cause the nanogel particles to swell and shirnkage, allowing controlled dosing of the drug contained in capsules. The developed nanogels are promising materials with great potential for biomedical applications.

Keywords: stimuli-responsive polymers, thermo-responsive nanogels, 2-(dimethylamino)ethyl methacrylate, $\mathrm{N}$-isopropylacrylamide, poly(vinylpyrrolidone), poly(ethylene glycol) diacrylate, lower critical solution temperature.
\end{abstract}

\section{Nanożele otrzymane $w$ wyniku polimeryzacji indukowanej promieniowaniem gamma*)}

Streszczenie: Zbadano wpływ stężenia metakrylanu 2-(dimetyloamino)etylu (DMAEMA) na wrażliwość na temperaturę nanożeli otrzymanych na bazie $N$-izopropyloakrylamidu (NIPAAM), poli(winylopirolidonu) (PVP), diakrylanu poli(glikolu etylenowego) (PEGDA) metodą polimeryzacji indukowanej promieniowaniem gamma. Do scharakteryzowania nanożeli stosowano pomiary dynamicznego rozpraszania światła (DLS) i potencjału Zeta. Wykazano wpływ temperatury na pęcznienie i kurczenie się cząstek nanożelu, co umożliwia kontrolowane dozowanie leku zawartego w kapsułkach. Opracowane nanożele są obiecującymi materiałami o dużym potencjale do zastosowań biomedycznych.

Słowa kluczowe: polimery reagujące na bodźce, nanożele reagujące na temperaturę, metakrylan 2-(dimetyloamino)etylu, $\mathrm{N}$-izopropyloakryloamid, poli(winylopirolidon), diakrylan poli(glikolu etylenowego), dolna krytyczna temperatura roztworu.

\footnotetext{
1) Malaysia-Japan International Institute of Technology, Universiti Teknologi Malaysia, Jalan Sultan Yahya Petra, 54100 Kuala Lumpur, Malaysia.

2) Nanotechnology Laboratory, Radiation Processing Technology, Malaysian Nuclear Agency, 43800 Dengkil, Selangor, Malaysia.

*) Material contained in this article was presented at the 1st Malaysia International Conference on Nanotechnology \& Catalysis (MICNC 2021), 1-3 September 2021, Malaya, Malaysia.

**) Author for correspondence: m_yusof@nuclearmalaysia.gov.my
} 
The use of smart drug-delivery systems based on stimuli-responsive polymers has recently received much attention due to their advances in the controlled release of anti-cancer drugs in response to produced stimuli. NIPAAM is one of the finest-acknowledged thermo-sensitive polymers used for drug delivery applications [1] as it offers abundant capability attributable to its amphiphilicity, biodegradability, and undeniably sensitivity to an external temperature stimulus $[2,3]$. Because of its thermally reversible collapse behavior at higher temperatures of its LCST, NIPAAM may also operate as an on/ off switch for drug release [4]. Conversely, the LCST of NIPAAM is beneath $37^{\circ} \mathrm{C}$, which will limit its application in cancer-targeted drug delivery as it would precipitate the instant it is introduced into the human body and lost the thermal targeting function [5]. Thus, NIPAAM is frequently copolymerized with other materials to tune the LCST of NIPAAM $\left(32^{\circ} \mathrm{C}\right)$ above body temperature [4, 6-7].

LCST tuning of thermosensitive polymers has been a subject of intense studies to give this class of material advantage in applying targeted drug delivery. The LCST of thermosensitive polymers depends on their hydrophobic or hydrophilic moieties on their main chains [8]. Generally, the LCST can be increased or decreased by copolymerization of hydrophilic or hydrophobic moieties, respectively. In this study, PVP and PEGDA are copolymerized onto PNIPAAm to form nanogels with amphiphilic property with their hydrophobic cores directed inward and hydrophilic comprising hydrated amides outer layers $[9,10]$, hence providing stealth properties to the resulting nanogels. Additionally, NIPAAM [11], PVP, and PEGDA [12] are among the many polymers listed under USFDA-approved materials for various biomedical applications that exhibit low biocompatibility and immunogenicity. The LCST of nanogels can be studied using dynamic light scattering, where a sudden drop in size can be observed.

Since the earliest application of DMAEMA as a drug carrier in 1987 by Sefton and his coworkers [13], a wide range of polymers with various chemical structures and properties have been produced, investigated, and analyzed in drug delivery systems. Because of its unique ionic strength and chemical functionalization, DMAEMA is a thoroughly researched polymer [14, 15]. Besides, it is non-toxic, water-soluble [16], biocompatible [17], charged macromolecule [18], possesses extraordinary $\mathrm{pH}$ responsiveness in acidic environments and is non-toxic to live creatures [19]. DMAEMA is one of the most studied temperatures and $\mathrm{pH}$-responsive polymers, as its LCST value is close to the body temperature [20]. Thus, DMAEMA is a rigid substrate for various applications, including drug delivery systems.

Several studies have been performed to fortify the thermosensitivity of copolymerized DMAEMA nanogel. Wang and colleagues discovered that their P(NIPAAmco-DMAEMA) copolymerized hydrogels had a high thermosensitivity, as evidenced by their fast deswelling rate and visible LCSTs with remarkable $\mathrm{pH}$ and temperaturesensitive features [16]. Motaali et al. [21] also discovered that their (NIPAAM-DMAEMA)-Fe3O4 polymer created via free-radical emulsion polymerization could be employed for regulated drug delivery due to its ther$\mathrm{mal} / \mathrm{pH}$ sensitivity. In aqueous media, the poly(ethylene oxide)-b-PDMAEMA-b-PNIPAAm) copolymer polymerized via surface-initiated reversible addition-fragmentation chain transfer (RAFT) demonstrated both temperature and $\mathrm{pH}$ sensitivity [22].

Briefly, the main principle of this research is to strengthen the thermosensitivity of copolymerized nanogels. Although the evidence of NIPAAM-DMAEMA copolymerized with other materials [16, 23-25] has been established in the literature, no such relationship has been investigated within NIPAAM-PVP-PEGDA-DMAEMA copolymerization. This study's novelty also consists in utilizing gamma radiation-induced copolymerization in tuning the LCST value of drug delivery material. To the best of our knowledge, it is the first attempt to alter the LCST value using the way mentioned above. Herein, we present the synthesis of P(NIPAAM-PVP-PEGDA-DMAEMA) nanogel via gamma radiation-induced polymerization method as an alternative to the conventional classical chemistry methods. This polymerization method avoids using toxic chemical initiators and crosslinkers that are difficult to remove, resulting in a cleaner product.

\section{EXPERYMENTAL PART}

\section{Materials}

NIPAAM (99.9\%), PVP (99.9\%), PEGDA (98.9\%), and DMAEMA (98.9\%) were acquired from Sigma-Aldrich and used without prior purification. For all solution preparations, ultrapure water was used throughout this experiment.

\section{Synthesis of thermosensitive nanogel}

NIPAAM, PVP, PEGDA, and DMAEMA were dissolved in water at varying molar ratios, with the concentration of DMAEMA incrementally rising as the sample ascended (Table 1). The identical conditions were used to create the NIPAAM, PVP, PEGDA hydrogel without DMAEMA as a control, labelled as sample A. The mixture was aliquoted into various vessels, and $30 \mathrm{~min}-$ utes before gamma irradiation, the oxygen content was purged with nitrogen gas. Each vessel's radiation doses were 5 kGy, 10 kGy, 15 kGy, 20 kGy, and 25 kGy. The aliquots were then purged with nitrogen gas for a further 30 minutes following irradiation. Then, using a 12,000 Da molecular cutoff membrane, the aliquots were dialyzed against water for 48 hours. Shimadzu UV-1700, at $280 \mathrm{~nm}$ wavelength, was used to monitor the dialysis procedure. After lyophilization, the samples were resuspended in ultrapure water for further characterization and testing. 
T a b l e . 1. Molar ratio of premixed samples

\begin{tabular}{c|c|c|c|c}
\hline Sample & NIPAAM & PVP & PEGDA & DMAEMA \\
\hline A & 85 & 5 & 5 & 0 \\
B & 85 & 5 & 5 & 5 \\
C & 85 & 5 & 5 & 10 \\
D & 85 & 5 & 5 & 20 \\
\hline
\end{tabular}

\section{Dynamic light scattering study}

At $25,30,35$, and $40^{\circ} \mathrm{C}$, dynamic light scattering was used to determine the size (hydrodynamic diameter) and photon scattering intensity of the resulting nanogel. Nanophox from Sympatec $\mathrm{GmbH}$ was used to generate a $10 \mathrm{~mW}$ HeNe laser beam with a wavelength of $632.8 \mathrm{~nm}$ and a scattering angle of $90^{\circ}$ at a temperature of $25^{\circ} \mathrm{C}$. The conditions of measurement were established according to earlier reports [10]. The lyophilized and loaded nanogels were redispersed in ultrapure water and filtered through a $0.22 \mathrm{M}$ pore filter. The scattering intensity of the particles was determined using the 3D cross-correlation function and examined using cumulant analysis to determine their hydrodynamic diameter and dispersity.

\section{Zeta potential study}

Zeta potential electrophoresis (ZetaPlus, Brookhaven Instruments, USA) was used to determine the P(NIPAAM-PVP-PEGDA-DMAEMA) nanogel's total surface charge. The zeta potential analyzer was measured at $25^{\circ} \mathrm{C}$ to study its stability upon loading the drug and total surface charge.

\section{RESULTS AND DISCUSSION}

\section{Synthesis and characterization of thermosensitive nanogel}

Because the thru effect on the polymers' solution was minimal upon irradiation, the irradiated polymeric mixture of P(NIPAAM-PVP-PEGDA-DMAEMA) nanogel was expected to create random copolymers (Figure 1). The polymeric structures formed by the grafting were

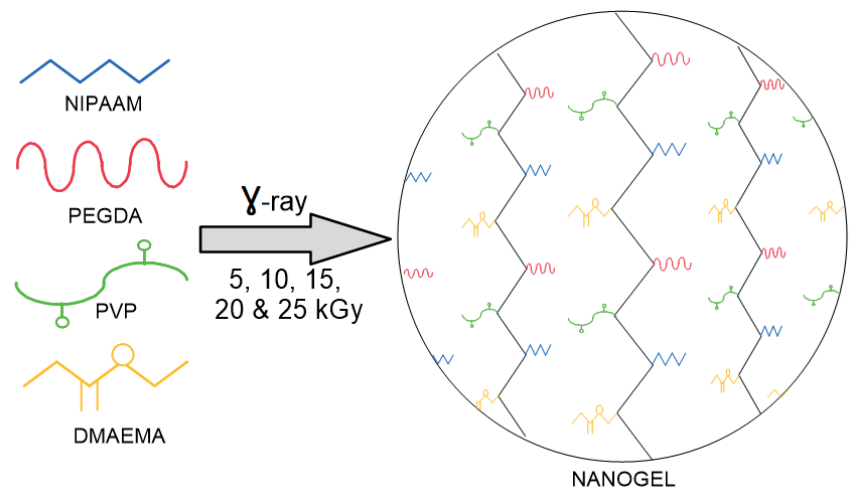

Fig. 1. Synthesis of P(NIPAAM-PVP-PEGDA-DMAEMA) nanogels amphiphilic, with a hydrophobic core and a hydrophilic shell. The proposed copolymer structure is visualized in Figure 2.

\section{Thermosensitive nanogel size: effect of differential temperature}

According to Zhang [26] and Yin, adjusting the precursor concentration allows for easy control of the nanogel's size. Thus, in this study, DMAEMA was dissolved in water at varied molar ratios, with the concentration of DMAEMA rising incrementally for samples B, C and D. The LCST of nanogels was investigated using dynamic light scattering reveals a decrease in size. A declined in overall nanogels size from 25 to $40^{\circ} \mathrm{C}$ (Figure 3) for all samples A, B, C and D at different dosages indicated that temperature expectedly contributed to the swelling of nanogel. As the temperature rises over the LCST, the hydrophobic hydrogen bonds in the polymer backbone weaken, become partially dehydrated, and can no longer be solubilized, causing the collapse of the polymer [27-33], thus initiating the release of encapsulated drugs. This illustrated that the hydrophilic DMAEMA does assist in raising the LCST.

Moreover, the size of these P(NIPAAM-PVP-PEGDADMAEMA) nanogels ranged from 134 to $447 \mathrm{~nm}$. In the $70-200 \mathrm{~nm}$ range, they were widely considered to be of the appropriate size for nanogels in drug delivery applications [34]. However, particles larger than $200 \mathrm{~nm}$ will be opsonized. Opsonization will accumulate in the liver and spleen, which leads to a higher risk of aggregation. Figure 3 also demonstrateds that the size of P(NIPAAM-PVP-PEGDA-DMAEMA) nanogels (Sample $\mathrm{B}, \mathrm{C}$, and D) correspondingly decreased with the rise of DMAEMA concentration. With the highest concentration of DMAEMA, Sample D showed the smallest nanogels size of $134 \mathrm{~nm}$ to $223 \mathrm{~nm}$. As the temperature escalated, the hydrophilicity of DMAEMA in the DMAEMA-NIPAAM copolymer composition increased, which led to a higher LCST and swelling ratio [16, 35]. Therefore, the size decreased gradually. Thus, it is plausible to expect that when the nanogel reaches the LCST, it will collapse, thereby initiating the release of the encapsulated drugs.

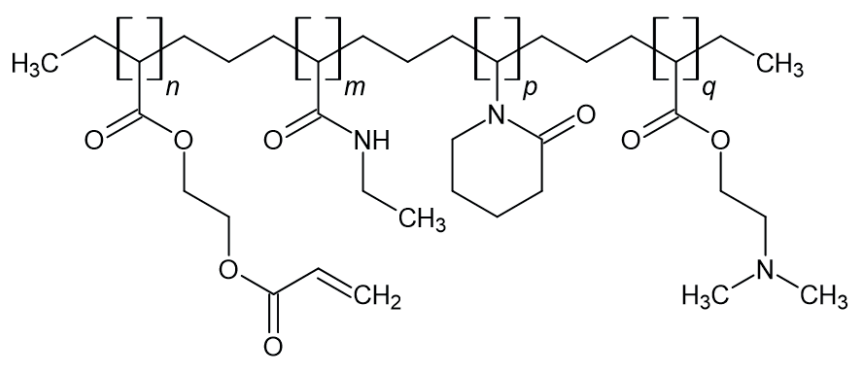

Fig. 2. Copolymer structure suggestion of gamma induced copolymerization reaction 

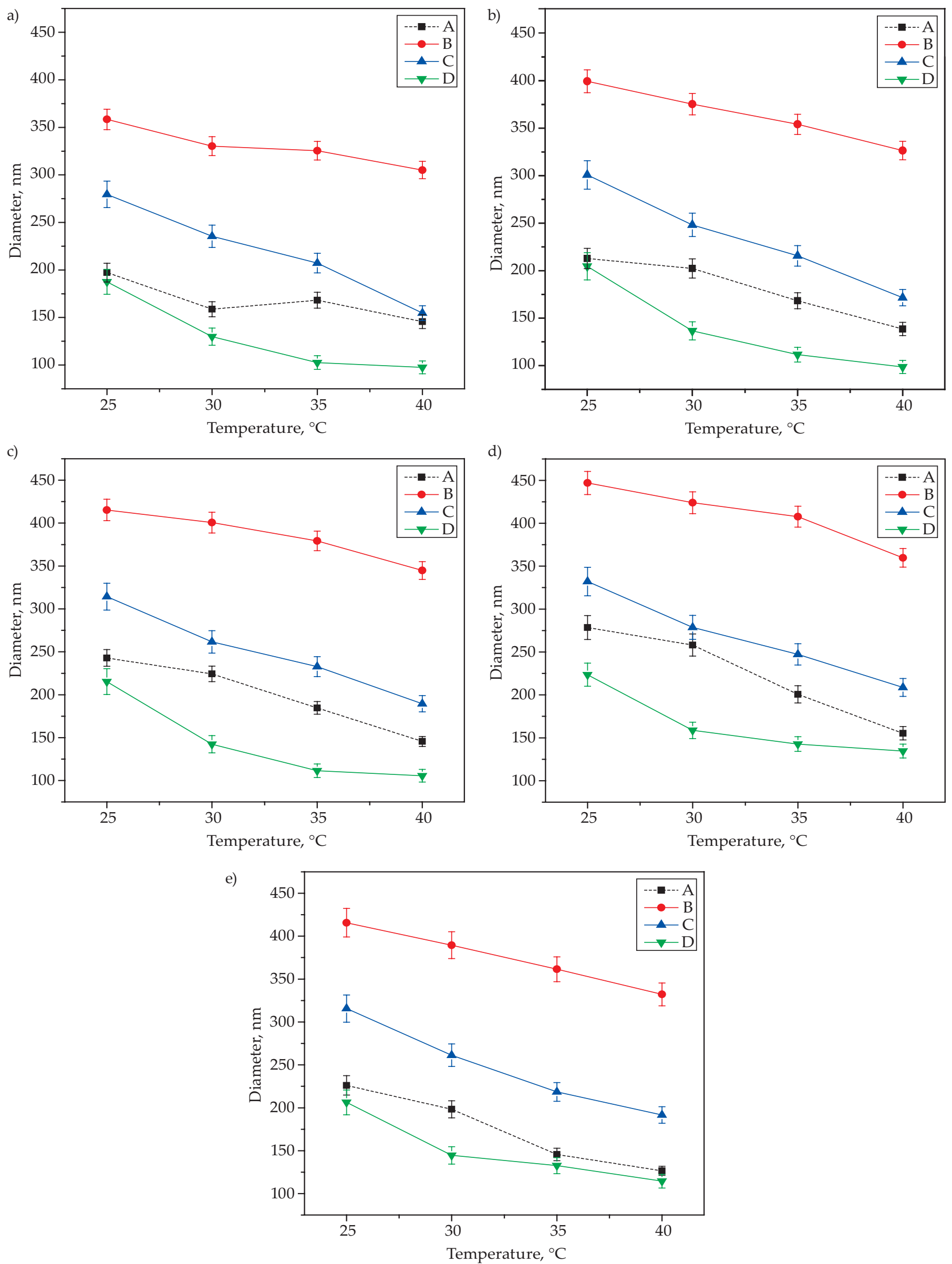

Fig. 3. Size of P(NIPAAM-PVP-PEGDA-DMAEMA) nanogel as a function of irradiation dose: a) 5kGy, b) 10kGy, c) 15kGy, d) 20kGy, e) 25kGy 

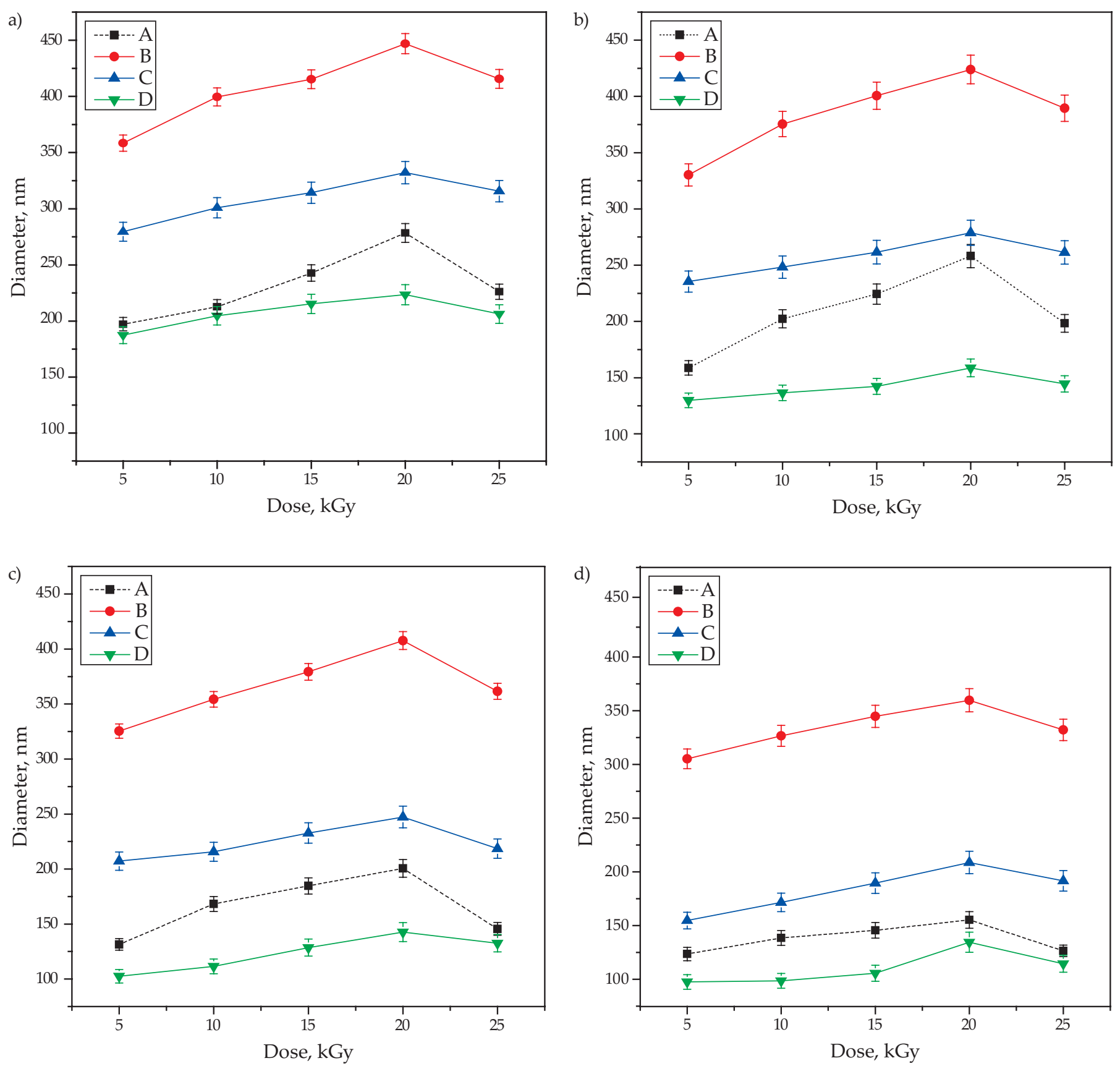

Fig. 4. Size of P(NIPAAM-PVP-PEGDA-DMAEMA) nanogel as a function of temperature: a) $25^{\circ} \mathrm{C}$, b) $\left.30^{\circ} \mathrm{C}, \mathrm{c}\right) 35^{\circ} \mathrm{C}$, d) $40^{\circ} \mathrm{C}$

\section{Thermosensitive nanogel size: effect of differential dosage}

The size of the P(NIPAAM-PVP-PEGDA-DMAEMA) nanogels increased at higher irradiation dose up to 20 kGy (Figure 4), which was consistent with nanogel aggregation [36, 37], but then declined for all samples. This was due to the fact that the P(NIPAAMPVP-PEGDA-DMAEMA) nanogels have reached their maximum polymerization. The surface energy of the P(NIPAAM-PVP-PEGDA-DMAEMA) nanogels plays a key role in situating the atoms and the chosen polymer once they interrelate with the high energy of gamma rays $[38,39]$. Similarly, Kozlovskiy and the associates [40] determined that an escalation in the gamma irradiation dose influences polymer size enlargement. As a result, the $20 \mathrm{kGy}$ dosage samples will be chosen for future investigation.

Meanwhile, the polymer size reduction at 25 kGy can be attributed to gamma irradiation's thin films' ionization [41]. At higher gamma doses, the polymer adapted by changing the atoms from their regular site and segregating them into tiny fragments, initiating the polymer size reduction. It demonstrates that the $25 \mathrm{kGy}$ dosage is insufficient for further study of these samples. The polymerized results in nanogels also show a simi- 


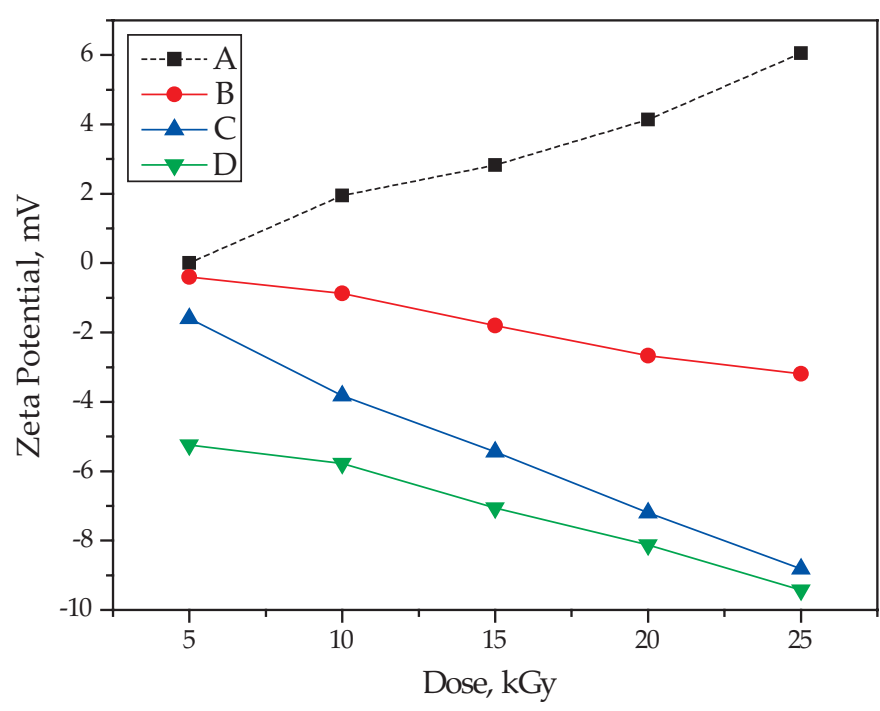

Fig. 5. Zeta potential of P(NIPAAM-PVP-PEGDA-DMAEMA) nanogel as a function of irradiation dose

lar trend in which the dropped in size of samples B, C, and $\mathrm{D}$, within the range of $416 \mathrm{~nm}$ to $188 \mathrm{~nm}$, increases gamma irradiation dose.

\section{Zeta Potential Study}

The durability of nanogel is critical since it limits the nanogel's long-term storage stability and capacity to load pharmaceuticals while maintaining its monodispersity. The zeta potential is an essential parameter in determining stability. The zeta potential values of the nanogel as a function of concentration and drug concentration were investigated in this study at room temperature. This assesses the nanogel's safe concentration or how much drug may be safely contained in the nanogel before aggregation begins. The zeta potential increases with concentration, as illustrated in Figure 5 for the control sample. The maximum stability of the zeta potential values in the radiation dose range was $6.05 \mathrm{mV}$. At this dosage the nanogel begins to form small aggregates with the highest joint surface charge density [42].

Nonetheless, with more significant concentrations of P(NIPAAM-PVP-PEGDA-DMAEMA) nanogel, the zeta potential diminishes, indicating that the increased sizes of the nanogel overcame the influence of the joint surface charge. The zeta potential ranged from -0.40 to $-9.43 \mathrm{mV}$. Overall, the loaded nanogel had lower zeta potential values than the control sample nanogel. This could be due to DMAEMA's steric stability following the combination with the nanogel. The colour changes of P(NIPAAMPVP-PEGDA-DMAEMA) nanogels can be observed in Figure 6, where it became cloudier as irradiation dose exposure increased.

This situation can be related to the polymerization of P(NIPAAM-PVP-PEGDA-DMAEMA) nanogels where the radiation exposure can be accumulated overexposure [43]. The more radiation is exposed to the samples,

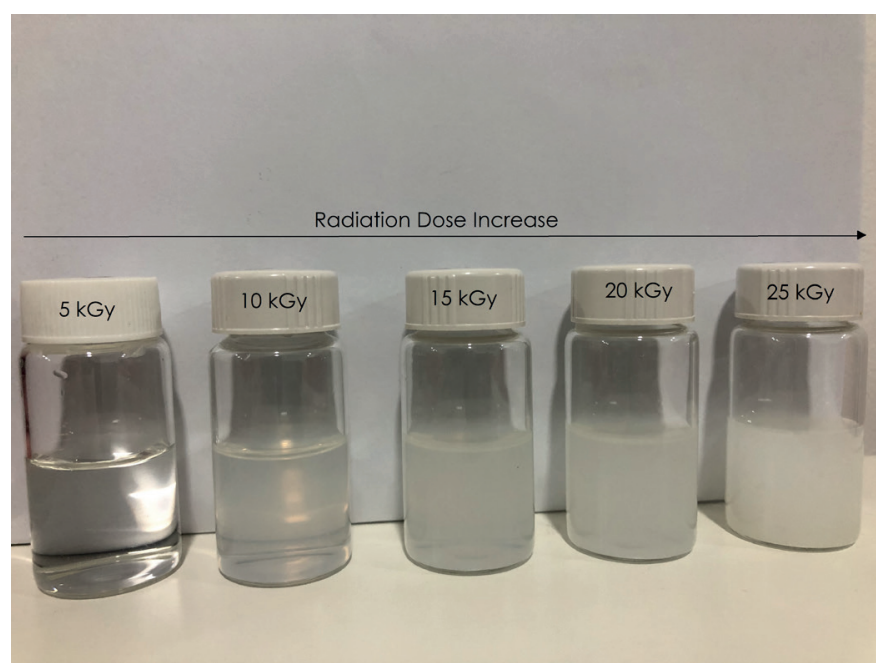

Fig. 6. Color changes in samples in response to irradiation dosage

the longer the exposure time. Polymerization causes the samples to be milky-looking due to the light scattering from atoms' segregating into small fragments in the nanogels.

\section{CONCLUSION}

In this study, a variety of P(NIPAAM-PVP-PEGDADMAEMA) nanogels was synthesized and prepared in single step using a carcinogenic-free and ecologically friendly gamma radiation-induced copolymerization technique. A decline in P(NIPAAM-PVP-PEGDADMAEMA) nanogels size at the elevated temperature indicated that temperature contributed to the swelling of nanogel (decrease in size), thus initiating encapsulated drugs above the LCST. P(NIPAAM-PVP-PEGDADMAEMA) nanogel shows a promising material system and has promising potential in the drug delivery system as higher DMAEMA concentration seems to encourage the formation of nanogel and the shrinkage at the same formulation. The optimum irradiation dosage of P(NIPAAM-PVP-PEGDA-DMAEMA) nanogels for further investigation, sample D is $20 \mathrm{kGy}$. This study will contribute to new knowledge and may even be applied to tuning the LCST of any other drug delivery material.

\section{ACKNOWLEDGEMENTS}

The authors appreciatively acknowledge services and facilities at Nanotechnology Laboratory, Radiation Processing Technology Division, Malaysian Nuclear Agency. The authors are obliged to recognize the Malaysia-Japan International Institute of Technology (MJIIT), UTM KL, for the support. The authors wish to extend their gratitude to the Government of Malaysia and the Ministry of Science, Technology, and Innovation, MOSTI, for funding this project through Grant Scheme, FRGS/1/2019/TK05/MOSTI/02/1. 


\section{REFERENCES}

[1] Farshbaf M., Salehi R., Annabi N. et al.: Drug Development and Industrial Pharmacy 2018, 44, 452. https://doi.org/10.1080/03639045.2017.1397686

[2] Liu Y., Cao X., Luo M. et al.: Journal of Colloid and Interface Science 2009, 329, 244.

https://doi.org/10.1016/j.jcis.2008.10.007

[3] Zhang X., Lü S., Gao C. et al.: Nanoscale 2013, 5, 6498. https://doi.org/10.1039/C3NR00835E.

[4] Akbarzadeh A., Samiei M., Joo S.W. et al.: Journal of Nanobiotechnology 2012, 10, 1. https://doi.org/10.1186/1477-3155-10-46

[5] Yang M., Ding Y., Zhang L. et al.: Journal of Biomedical Materials Research Part A 2007, 81, 847. https://doi.org/10.1002/jbm.a.31129

[6] Meyer D.E., Shin B.C., Kong G.A. et al.: Journal of Controlled Release 2001, 74, 213. https://doi.org/10.1016/S0168-3659(01)00319-4

[7] Zintchenko A., Ogris M., Wagner E.: Bioconjugate Chemistry 2006, 17, 766. https://doi.org/10.1021/bc050292z

[8] Zhang Q., Weber C., Schubert U.S. et al.: Materials Horizons 2017, 4, 109. https://doi.org/10.1039/c7mh00016b

[9] Salehi P., Makhoul G., Roy R. et al.: Journal of Biomaterials Science, Polymer Edition 2013, 24, 574. https://doi.org/10.1080/09205063.2012.700111

[10] Hamzah M.Y., Hashim S., Aizan W.A.R.W.: International Journal of Polymeric Materials and Polymeric Biomaterials 2017, 66, 926. https://doi.org/10.1080/00914037.2017.1291512

[11] Chatterjee S., Chi-Leung Hui P.: Molecules 2019, 24(14), 2547. https://doi.org/10.3390/molecules24142547

[12] Tan H., Marra K. G.: Materials 2010, 3, 1746. https://doi.org/10.3390/ma3031746

[13] Sefton M.V., Broughton R.L., Sugamori M. E. et al.: Journal of Controlled Release 1987, 6, 177. https://doi.org/10.1016/0168-3659(87)90075-7

[14] Lechuga-Islas V.D., Festag G., Rosales-Guzmán M. et al.: European Polymer Journal 2020, 124, 109457. https://doi.org/10.1016/j.eurpolymj.2019.109457

[15] Hu Y., Wang J., Zhang H. et al.: Materials Science and Engineering: C, Materials for Biological Applications 2014, 45, 1. https://doi.org/10.1016/j.msec.2014.08.061

[16] Wang B., Xu X.D., Wang Z.C. et al.: Colloids Surf B Biointerfaces 2008, 64, 34.

https://doi.org/10.1016/j.colsurfb.2008.01.001

[17] Perevyazko I., Lezov A., Gubarev A.S. et al.: Polymer 2019, 182, 121828. https://doi.org/10.1016/j.polymer.2019.121828

[18] Boyer C., Boutevin G., Robin J.J. et al.: Polymer 2004, 45, 7863.

https://doi.org/10.1016/j.polymer.2004.09.020
[19] Seema A., Yi Z., Samarendra M. et al.: Materials Today Communications, 2012, 15, 388. https://doi.org/10.1016/S1369-7021(12)70165-7

[20] Hajebi S., Abdollahi A., Roghani-Mamaqani H. et al.: Polymer 2019, 180, 1.

https://doi.org/10.1016/j.polymer.2019.121716.

[21] Motaali S., Pashaeiasl M., Akbarzadeh A. et al.: Artificial Cells, Nanomedicine and Biotechnology 2017, 45,560 . https://doi.org/10.3109/21691401.2016.1161640

[22] Xu E., Liu C., Huang J.: Journal of Applied Polymer Science 2008, 108, 2180. https://doi.org/10.1002/app.27880

[23] Xu F.J., Kang E.T., Neoh K.G.: Biomaterials., 2006, 27, 2787.

https://doi.org/10.1016/j.biomaterials.2006.01.003

[24] Razavi B., Abdollahi A., Roghani-Mamaqani H. et al.: Materials Science and Engineering: C, Materials for Biological Applications 2020, 109, 110524. https://doi.org/10.1016/j.msec.2019.110524

[25] Meléndez-Ortiz I. H., Bucio E.: Designed Monomers and Polymers 2012, 12, 99. https://doi.org/10.1163/156855508x391167

[26] Zhang X., Achazi K., Steinhilber D. et al.: Journal of Controlled Release 2014, 174, 209. https://doi.org/10.1016/j.jconrel.2013.11.005

[27] Zhang H., Zhai Y., Wang J. et al.: Materials Science and Engineering: $C$, Materials for Biological Applications 2016, 60, 560 .

https://doi.org/10.1016/j.msec.2015.11.041

[28] Cabane E., Zhang X., Langowska K. et al.: Biointerphases 2012, 7, 9. https://doi.org/10.1007/s13758-011-0009-3

[29] Qureshi D., Nayak S.K., Maji S. et al.: European Polymer Journal 2019, 120, 109220. https://doi.org/10.1016/j.eurpolymj.2019.109220

[30] Preman N.K., Barki R.R., Vijayan A. et al.: European Journal of Pharmaceutics and Biopharmaceutics 2020, 157, 121.

https://doi.org/10.1016/j.ejpb.2020.10.009

[31] Konefał R., Spěváček J., Mužíková G. et al.: European Polymer Journal 2020, 124, 109488. https://doi.org/10.1016/j.eurpolymj.2020.109488

[32] Das S.S., Bharadwaj P., Bilal M. et al.: Polymers 2020, 12, 1397. https://doi.org/10.3390/polym12061397

[33] Huang H., Qi X., Chen Y. et al.: Saudi Pharmaceutical Journal 2019, 27, 990. https://doi.org/10.1016/j.jsps.2019.08.001

[34] Hamzah M.Y., Hashim S., Aizan W.A.R.W.: Journal of Polymer Research 2017, 24, 134. https://doi.org/10.1007/s10965-017-1281-9

[35] Klouda L.: European Journal of Pharmaceutics and Biopharmaceutics 2015, 97, 338. https://doi.org/10.1016/j.ejpb.2015.05.017

[36] Rezaei T., Nabid M. R., Niknejad H. et al.: Polymer 2012, 53, 3485. 
https://doi.org/10.1016/j.polymer.2012.05.056

[37] Hamzah Y., Yunus W.M.Z.W., Isa N.M. et al.: e-Polymers, 2012, 45.

https://doi.org/10.1515/epoly.2012.12.1.533

[38] Sudha A., Sharma S.L., Sharma S.D.: Journal of Materials Science: Materials in Electronics 2016, 28, 4619. https://doi.org/10.1007/s10854-016-6100-2

[39] Aldawood S., AlGarawi M.S., Shar M.A. et al.: Journal of King Saud University - Science 2020, 32, 2629. https://doi.org/10.1016/j.jksus.2020.05.004
[40] Kozlovskiy A., Dukenbayev K., Kenzhina I. et al.: Ceramics International 2018, 44, 19787. https://doi.org/10.1016/j.ceramint.2018.07.235

[41] Ahmed Ali A.M., Ahmed N.M., Mohammad S.M. et al.: Results in Physics 2019, 12, 615. https://doi.org/10.1016/j.rinp.2018.10.066

[42] Bhattacharjee S.: Journal of Controlled Release 2016, $235,337$. https://doi.org/10.1016/j.jconrel.2016.06.017

[43] Kim J.H.: Korean Journal of Pain 2018, 31, 145. https://doi.org/10.3344/kjp.2018.31.3.145

Recceived 18 VIII 2021.

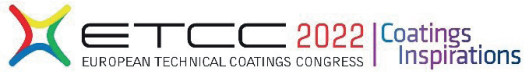

\section{Kongres ETCC2022 NOWY TERMIN 12-14 lipca 2022}

$\mathrm{Z}$ powodu światowych restrykcji związanych z pandemią SARS CoV-2, nowy termin kongresu ETCC2022 - European Technical Coatings Congress (poprzednio ETCC2020) ustalony na 12-14 lipca 2022 w Krakowie

Prezentacje ETCC2022 dotyczą najnowszych osiągnięć nauki i techniki w zakresie:

farb, lakierów, surowców, klejów, materiałów budowlanych, technologii

i koncepcji z nimi związanych.

Nowy, dodatkowy TERMIN ZGŁASZANIA ABSTRAKTÓW: 30 STYCZNIA 2022

Najważniejsze Fakty dotyczące Kongresu:

$\checkmark$ Program ETCC2022 zawiera 138 referatów oraz 68 prezentacji posterowych przedstawianych przez 200 autorów z wielu krajów całego świata. Szczegóły w programie kongresu: www.etcc2022.org/en/congress/congress-program

$\checkmark$ Możliwość publikowania wystapień kongresowych w renomowanych czasopismach, szczegóły: www.etcc2022.org/en/congress/publication-in-journals

$\checkmark$ Przygotowano wystawę towarzyszącą kongresowi, szczegóły dostępne na www.etcc2022.org/en/congress/registration-form-for-exhibitors

$\checkmark$ Ustalono program sesji "Summer School" dedykowanej młodym naukowcom. www.etcc2022.org/en/congress/summer-school

ETCC2022. Innowacje i Wymierne Korzyści:

W ciągu trzech dni kongresu odbędą się prezentacje plenarne, 6 sesji równoległych, prezentacje posterów oraz wystawa.

Prelegenci reprezentują największe firmy, instytuty i uniwersytety całego świata

Wszystkie dotychczasowe warunki i ustalenia, w tym:

$\checkmark$ Rejestracja do udziału w kongresie

$\checkmark$ Dokonane opłaty kongresowe

$\checkmark$ Przesłane wystąpienia: referaty oraz postery

$\checkmark$ Rejestracje do udziału w wystawie

$\checkmark$ Zgłoszenia do sesji „Summer School” dla młodych naukowców

Pozostają ważne w nowym terminie kongresu.

Organizatorzy kongresu ETCC2022:

Europejska Federacja FATIPEC - Federation of Associations of Technicians for Industry of Paints in European Countries (www.fatipec.com), oraz

Stowarzyszenie Inżynierów i Techników Przemysłu Chemicznego SITPChem (www.sitpchem.org.pl)

W przypadku pytań prosimy o kontakt, e-mail: etcc2022@sitpchem.org.pl 